\title{
Soyinka and Yoruba Sculpture: Masks of Deification and Symbolism
}

\author{
Gilbert Tarka Fai \\ University of Maroua, Cameroon
}

\begin{abstract}
The Yoruba mask is a piece of sculpture that is both artistic and functional. The carved work fulfils one or more of several functions-sacred or profane, personal or communal, serious or satirical. As an object it has only its relatively insignificant quota of vital energy that is found, according to African ontology, in all matter and substance of the visible world- animal, vegetable and mineral. But the Yoruba mask also has a force that extends to the world of spirits and gods. These masks also have the dual effect of transforming the wearer and the ambivalence of serving good and evil ends. This indicates that the Yoruba mask apart from its spiritual essence is a symbol of great complexity and ambiguity. It is from this great community of sculptors and from the ambivalent quality of the mask as image and symbol that some of Wole Soyinka's creative writings emerge. This paper argues that Wole Soyinka uses his native Yoruba sculpture, and the mask in particular, to dramatise the essential spiritual continuity of human nature through the dramatic appearance of gods and the spirits of the ancestors in the world of the living during the dance of possession.
\end{abstract}

[Key words: Soyinka, Yoruba, sculpture, masks, symbolism.]

Traditional Yoruba life is dominated by religion and they are surrounded by innumerable gods and spirits with whom the lives of mortals interact. Below the deities are spirits including the spirits of the departed ancestors. Apart from the supreme deity (Olodumare or Olorun) who is never represented by a carving (because a Yoruba would not know what he looked like), other gods and spirits are represented by masks and statues which are kept in shrines where they are worshipped. Ogun, Soyinka's favourite god, for example, is always represented with a carving of a snake eternally devouring its own tail. Soyinka was drawn in particular to this god's ambivalent role. As god of war, Ogun embodies the destructive principle. In addition to his function as god of Iron and Metallurgy, Patron of Hunting and Guardian of the Road, he is also the creative essence. He is at once destroyer and creative impulse. This makes him an enigmatic symbol both in Soyinka's own creative work and in his criticism. Man in his capacity both for creation and destruction is a reincarnation of this contradictory god.

The ancestors are worshipped through the egungun masked figures. The egungun is a cult of ancestors. It is a proof that the present generations of the Living do not stand alone, nor is the individual ever abandoned entirely to the limits of his own powers, for the dead ancestors continue to watch over and guide their descendants. The egungun society is a special custodian of the ancestral spirits. Basically, it is an attempt to reassure people about individual immortality and to diminish the fear of death through the dramatic appearance of the ancestral spirits within the world of men. It should be noted that not all ancestors have masks dedicated to them. When a particular ancestor is selected for worship, a mask is carved for him. The Ifa Society, a cult of divination, decides

\footnotetext{
Rupkatha Journal on Interdisciplinary Studies in Humanities

Volume 2, Number 1, Special Issue, Visual Arts

URL of the Issue: http://rupkatha.com/rupkathav2n1.php

PDF URL of the article:

http://rupkatha.com/V2/n1/SoyinkaandYorubaSculpture.pdf

(c) www.rupkatha.com
} 
which dead are to have masks dedicated to them. A member of the egungun is secretly appointed to be mask keeper and dancer.

Yoruba wood carvers have always been of prime importance in Western Nigeria. Their carvings of gods and spirits, their followers and ancestors have been described and analysed fascinatingly by such authorities on Yoruba culture as Ulli Beier who says of Yoruba temple carvings: 'they help the worshippers achieve the calm state of receptiveness that is necessary if the god is to manifest himself during ceremonies.' Of the carvers themselves, Ulli Beier says:

The Yoruba carver represents this heightened state, this intensified experience which is the purpose of Orisha ${ }^{1}$ worship. The final impression of harmony which the carver achieves is the result of controlled tension, of rigid form imposed on the pressure which seems to come from the carving. (31)

The above comments serve to underline the importance and skill of Yoruba carvers but more especially to emphasise the power and life inherent in the mask once it is carved. No wonder that a sculptor plays a major role in one of Soyinka's plays- A Dance of the Forests. The action in this play revolves around a sculpture- 'the totem' which Demoke is invited to carve as part of the celebrations of the 'Gathering of the Tribes' (Nigerian Independence celebrations). The totem is to serve as a symbol for the great reunion. It is Demoke's skill and his remorse for causing his apprentice's death that Soyinka celebrates in contrast to the skill of hypocrisy, corruption and prostitution exhibited by the other characters.

\section{The Mask of God or Spirit}

In Soyinka's work the mask is presented as a medium through which gods and spirits become manifest in the world of the living. This occurs in special ceremonies intended for that purpose where the dance of possession becomes incumbent. According to Margaret Laurence (1968), when possession takes place, the spirit or god is believed to be actually and perceptibly present. The dancer's own spirit is suspended; his spirit momentarily departs-held in abeyance or hiatus and the spirit of the mask has taken over. When the wearer becomes subservient to the spirit of the mask, he is often able to perform with skill greater than his own (20). Laurence's comments suggests that the dance of possession is a moment when the gods through the agency of man partake in human affairs usually to prophesy or perform acts which humans on their own would be unable to.

In A Dance of the Forests during the 'Dance of Welcome', the masked humans in a state of possession by different spirits proclaim doom for the new Nigerian nation. The Spirit of Palm for example, envisions hatred, discord and eventual bloodshed:

White skeins wove me, I, Spirit of Palm

No course I red.

I who suckle blackened hearts, know

Heads will fall down

Crimson in their bed. (64)

This predicted chaos was to be confirmed ten years later with the bloody Nigerian civil war of 1970. When the masks are removed, the spirits depart and the human characters come back to normal and can no longer speak with a prophetic tongue. Similarly, they can no longer remember what they said. The masked, 
possessed humans who speak in the voice of gods in $A$ Dance of the Forests is a classic example of the 'god- apparent or god- become man phenomenon.

Perhaps it is in The Road that the spectacle of the 'god-apparent' is fully exploited. In this play, Soyinka uses the word 'egungun' to refer to the mask and its wearer, together, in various stages of possession. The mask by itself, when not being worn by its true wearer is simply the 'mask', a thing, a carved object. When the only man who can rightfully wear it puts it on, together they become the egungun. Margaret Laurence points out that with the traditional Yoruba egungun, the state of possession can take place only with the proper ritual, at the time of the festival, and with the accompaniment of the drums which speak the key phrases and establish the pattern and place of the entire procedure. The mask has to be treated in the proper ritualistic manner so that it will be kindly disposed towards the human community. It is always forbidden for anyone except the chief priest to know who dances under any particular mask. It is considered dangerous to go near an egungun. It is unthinkable to stage a masked performance and to bring about a possession without the proper ritual, the right time, the sanctioned means and the priest's supervision (21-48). What happens in The Road goes contrary to all the above and the consequences are inevitable.

The focal character in The Road is an absurdly enigmatic professor who is on a symbolic quest for the Word which he describes in various occasions as 'companion not to life, but death' (159); 'a golden nugget on the tongue' (180); 'a terrible fire' (192); 'that elusive kernel...the key, the moment of my rehabilitation' (202) and 'the scheme' (204). From these conflicting metaphorical definitions, Bernth Lindfors (1976) concludes that the Word is some form of cabalistic wisdom which is precious, powerful and associated with death and redemption (203). If Lindfors' definition is anything to go by, Professor's search may be viewed as a quest for the meaning of existence; or since it is a quest for the essence of death, it may be considered an attempt to seek immortality through the conquest of death itself. Professor believes that the key to immortality lies in the mystery of death, which is a monopoly of the gods. Just before the play opens, Murano in a state of possession has been struck and knocked down by the lorry-driver Kotonu at the moment when he was masquerading as the god Ogun at the annual Drivers' Festival. Kotonu and his mate Samson hide the body in the back of their lorry (to deceive the angry worshippers) and bring it to town. This is how Professor finds Murano and keeps him as his companion in order that he may learn from him the ultimate secrets of physical dissolution and the return to primal energy which underlies all existence. Soyinka explains this phenomenon very well in his prefatory note 'For the Producer':

The dance is the movement of transition; it is used in the play as a visual suspension of death in much the same way as Murano, the mute, is a dramatic embodiment of this suspension. He functions as an arrest of time, or death, since it was in his agemo phase that the lorry knocked him down. Agemo, the mere phase, includes the passage of transition from human to divine essence (as in the festival of Ogun in the play), as much as the part psychic, part intellectual grope of Professor towards the essence of death. (vi)

Professor keeps Murano with the hope of discovering the secret of transition if and when the mute's tongue is loosened. Professor keeps Murano because he is a man knocked down at the moment of his possession by the god Ogun when he had literally become the god-apparent. Being neither completely dead nor 
minimally alive, Murano has already acquired the ontological knowledge Professor desires but cannot pass it on to anyone in the world of the living. When the wait becomes interminable, Professor tries to stage a masked performance to bring about a possession without the proper ritual, the right time, the sanctioned means and the priest's supervision. This indirectly leads to Professor's death to confirm Margaret Laurence's warning. The events in The Road once more demonstrate the power of the Yoruba mask which serves as a medium for communion and communication between man and the supernatural.

Although in The Road Soyinka artistically employs egungun to refer to masks in general, the egungun among the Yoruba is principally an ancestral funerary cult as earlier stated. According to Gerald Moore (1971), when one of the members of this cult dies, the egungun surrounds his house with a ritual designed to show both the immortality of his spirit and the special character of his membership, now that he is no longer 'the mask of ancestors', but an ancestor himself. On the seventh day after the death of the husband, the widows are led out of town by a masked egungun to a clearing where moulds of earth have been heaped up to the number of the surviving wives. Each mould has a yam on it, which is taken by the widow as the last gift of her husband. But there is one additional mould with no yams, representing the dead man himself. After another week, a masked egungun comes to the house by night. The lights are put out and he calls upon the dead man. Another egungun behind the house replies in the voice of the deceased. Amid lamentations a dog is sacrificed and carried away. Next morning the masked egungun returns as the dead man to give last blessings to his family and receive presents. The egungun members then go to the forest groove to eat the dog (15). The above practice indicates that every stage in the gradual withdrawal of the dead man's presence and spirit from the intimacy of the household to After-life is clearly marked by a dramatic masked ritual that ensures continuous communion between the living and the ancestors.

\section{The Mask as Symbol}

The role of the Yoruba mask or sculpture is not only to create a link between existences. There are masks in addition to cult or sacred masks that perform different functions; for example, the 'Ghajero' mask quoted by Margaret Laurence referred to as hanger of witches-a grotesque mask whose wearer used to be responsible for executing people found guilty of witchcraft. This shows that some Yoruba masks in the past used to function as the police of the society. In The Swamp Dwellers, we learn that Igwesu keeps a mask in the village as a concrete symbol of his attachment to tradition unlike his twin brother in the city who has completely severed ties with tradition. The Yoruba mask therefore is evidence of one's cultural attachment.

In his work Soyinka uses the mask as a multifaceted symbol. According to L. Marfurt (1968), the mask has the dual effect of disguising or transforming the wearer and the ambivalence of serving good and evil ends (59). In A Dance of the Forests during the 'Dance of Welcome' intended to bring human criminals to justice, Forest Head (the Supreme Deity) masquerades as a filing clerk for the courts to carry out his design of letting the human characters judge themselves. Similarly, Eshuoro (a trickster and vengeful spirit) and Aroni (lame spirit and servant to Forest Head) masquerade as Questioner and The Figure in Red respectively. These masks make it possible for them to play their desired roles of judge and foe. 
Furthermore, Soyinka uses another sculpture-totem to underline the difference between tradition-bound masks and masks of hypocrisy and deception. Adenebi, a proponent of the carving of the totem, in the course of his conversation with Demoke's father declares:

'By the way, I really ought to tell you how disapointed I was with your son's handiwork. Don't you think it was rather pagan? I should have thought something more in keeping with our progress would be more appropriate' (31).

In fact, the work is in a sense pagan and also bestial. In Soyinka's view, it is, however, totally appropriate and in keeping with the progress of the new nation. The paganism and bestiality are in the subject of the sculpture, which ultimately symbolises the human society beyond the forest, not in the craftsmanship of the sculptor. According to Jonathan Peters (1978), Demoke has simply typified, through the totem, the continuing cycle of treachery that nullifies whatever progress that has been made. Adenebi's disenchantment with the totem, like the rejection of Dead Man and Dead Woman as guests at the Gathering, is an indication of the human distaste for the unvarnished truth. The 'accumulated heritage' which Adenebi says is being celebrated in this 'era of greatness' is less a record of goodness and justice than of villainy and violent injustice (173). Jonathan Peters' comments suggest that the totem which Demoke carves unconsciously becomes a fitting symbol of the turbulent times the nation is passing through.

The violent and bestial theme of the totem is therefore no accident since it represents the inherent properties of human nature. Like Sekoni's frenzied sculpting of 'The Wrestler' in The Interpreters, it is in addition a masterpiece. But although Demoke had a directive from the council to carve the totem, he was given no idea what it was intended for. The appropriateness of Demoke's theme as earlier stated derives from the psychic grasp of the spirit of the times. As he says,

For one thing, I did not know what it was all about. The council met and decided that they wanted it done. In secret. The tree was in the grove of $\mathrm{Oro}^{2}$, so it was possible to keep it hidden. Later I learnt that it meant for the gathering of the tribes. When I finished it, the grove was cleared of all other trees, the bush was razed and a motor road built up to it. It looked different. It was no longer my work. I fled from it. (11)

To Jonathan Peters, the above statement implies that the council, for all the eloquent speeches of its members, was planning to erect a monument to the nation without attaching any importance to the carving's motif. Not only do they show ignorance about their culture and its significance, but they are also insensitive to the artist's conception of his work. Concerned only with imagebuilding and publicity, they lay bare the area around the totem and build a motor road right up to it. The motor road and the cleared forest, Peters intimates, are symptoms of modern technological progress and civilisation; but the secularisation strips the totem of whatever sanctity it might have had and makes it a popular spectacle which its creator can no longer recognise as his work (176). The insensitivity of the councillors to the totem's intrinsic meaning and purpose consequently exposes their desire to return to the glory of past empires for cosmetic rather than metaphysical reasons, a hollow wishfulness rather than a serious commitment to tradition and culture, Peters concludes. Peters' comments above confirm Soyinka's distaste for masks of hypocrisy that are worn 
everyday in our society and he does this successfully through a sculpture-the totem which generates controversy amongst the very people who decided that it should be carved.

\section{Bibliography}

Bieir, Ulli. The Story of Sacred Wood Carvings from One Small Yoruba Town. Nigeria Magazine 1957, 31.

Jones, Eldred. The Writing of Wole Soyinka. London: Heinemann, 1973.

Laurence, Margaret. Long Drums and Cannons: Nigerian Dramatists and Nigerian Novelists. New York: Praeger, 1968.

Lindfors, Bernth. Wole Soyinka When Are You Coming Home?' Yale French Studies. No.53, 1976, 197-210.

Marfurt, L. 'Les masques africaines,' African Affairs. Winter, 1968, No.2, 59.

Moore, Gerald. Wole Soyinka. New York: African Publishing Corp., 1971.

Peters, Jonathan. A Dance of Masks: Sengor, Achebe, Soyinka. Washington DC: Three Continents Press, 1978.

Soyinka, Wole. A Dance of the Forests. Collected Plays 1. Oxford: O.U.P., 1973.

-The Road. Collected plays 1. Oxford: O.U.P., 1973.

-The Swamp Dwellers. Collected Plays 1. Oxford: O.U.P., 1973.

— The Interpreters. London: Heinemann, 1970.

Notes

1-orisha: the Yoruba word for god. Also the totality of the gods of the Yoruba pantheon.

2-Oro: a god of terror in the Yoruba pantheon.

Gilbert Tarka Fai is Lecturer, Department of English, Higher Teachers' Training College, University of Maroua, Cameroon. Email: tarkafai@gmail.com 